\title{
О ТИПОЛОГИИ БЕЗЭКВИВАЛЕНТНОЙ ЛЕКСИКИ
}

\section{ON THE TYPOLOGY OF NON-EQUIVALENT VOCABULARY}

\section{Bykova \\ A. Tadzhibova}

Summary: The article is devoted to the problem of the typology of nonequivalent vocabulary. This class of words is vast, and the words-realities denoting event names remain on the periphery of linguists' attention. For these units, the term evenonym is proposed. As a result of the analysis of the texts of the German press, three groups of eventonyms were defined.

Keywords: non-equivalent vocabulary, reality, eventonym, German, press, event.
Быкова Людмила Владимировна

К.филол.н., доцент, БУВО «Сургутский государственный университет» bykova_Iv@surgu.ru

Таджибова Аксана Наруллаховна К.филол.н., дочент, БУВО «Сургутский государственный университет» tadzhibova_an@surgu.ru

Аннотация: Статья посвящена проблеме типологии безэксивалентной лексики. Этот класс слов обширен, и на периферии внимания лингвистов остаются слова-реалии, обозначающие событийные имена. Для этих единиц предлагается термин эвеноним. Анализ текстов немецкой прессы позволил выделить три группы эвентонимов.

Ключевые слова: безэквивалентная лексика, реалия, эвентоним, немецкий язык, пресса, событие.

ка фразеологических единиц, фольклорные слова, слова нерусского происхождения [4, с. 269].

В данном исследовании используется классификации В.С. Виноградова, так как она представляется нам наиболее полной и охватывает все ключевые сферы жизнедеятельности. Ученый выделяет следующие категории:

1. Бытовые реалии;

2. Этнографические и мифологические реалии;

3. Реалии природного мира;

4. Реалии государственного строя и общественной жизни;

5. Ономастические реалии;

6. Ассоциативные реалии [6, с. 55].

В данной работе наше внимание сосредоточено на ономастических реалиях, а именно на именах, описывающих какие-либо события - эвентонимах.

Главной задачей ономастики является изучение имен собственных, а именно, людей, животных, мест и событий. Как правило, рассматривают их с культурологической, страноведческой точки зрения, как фоновую информацию при анализе отдельных произведениях, а не с лингвистической $[8,22]$.

Для систематизации онимов традиционно выделяют три уровня лексики: ядро, околоядерное пространство и периферия [5]. У каждого описываемого ядерного класса существует специальный термин, который, например, описывает название какого-либо места - «топоним», или какого-либо космического объекта - «астроним». Однако следует отметить, что, в отличие от ядерных онимов, единой системы классификации периферийных онимов на данный момент нет. Иерархические границы между 
периферийными онимами размыты, они не поддаются строгому и четкому структурированию, т.к. они отражают огромное разнообразие окружающей нас действительности [14].

Предметом нашего исследования является один из спорных вопросов номинации, проблема создания значимой языковой единицы для имен ситуаций (событий). Эти ситуации-события, традиционно относят к периферии ономастики, так как они отличаются слабой структурированностью и системностью [7].

Рассмотрим классификации периферийных онимов, предложенные И.В. Крюковой, Н.В. Подольской и А.В. Суперанской.

И.В. Крюкова в своем диссертационном исследовании предлагает следующую классификацию периферийных онимов: эргонимы - названия предприятий, гемеронимы - названия СМИ, геортонимы - названия праздников и мероприятий, прагмонимы - названия вещей, порейонимы - названия транспортных средств, фалеронимы - названия наград, медалей, знаков отличий и идеонимы - названия художественных произведений. По словам исследователя, это «практически вся «закавыченная» часть ономастического пространства» [10, с. 96].

Согласно наиболее общей классификации онимов А.В. Суперанской периферийные онимы можно разделить на две группы:

1. Названия неодушевленных предметов: хрематонимы; названия средств передвижения; сортовые и фирменные названия;

2. Собственные имена комплексных объектов: названия организаций; именования периодической печати; хрононимы; названия войн, кампаний, мероприятий; названия произведений искусств, литературы; документонимы; фалеронимы [12, с. 190].

Отметим, что во всех представленных классификациях выделяется пласт лексики, который авторы относят к разряду геортонимов и хрононимов. «Словарь русской ономастической терминологии» дает следующие определения для двух данных классов: разрядов: геортонимы (греч. દ́орти́ «праздник» + оним) - названия праздников; хрононимы (греч. хро́vо «время, пора» + оним) - названия исторически значимых отрезков времени [11, с. 17]. Однако данные разряды имен не носят комплексного характера, так «хрононимы» обозначают только исторически важные периоды и события, а «геортонимы» - только различные значительные мероприятия и праздники.

Обозначения различных событий в конце 90-х годов XX века стали объектом внимания немецких лингвистов. В результате появились два термина - симбантоним - symbantonym (от греч. symban, symbantos 'co- бытие'+ -оним) и феноменоним - phanomenonym (от греч. phainomenon 'явление'+ -оним) [14]. Профессор П.Н.Донец. предложила термин «эвентоним - eventonym» (от лат. eventus 'событие', 'случай' и греч. ynyma, ynoma 'имя'). Данный термин получил широкое распространение благодаря своему благозвучию. Автор предлагает определять эвентоним как событийное имя [14, с. 35]. В качестве примера подобных единиц исследователь приводит термин «Арабская весна», под которым понимается волна протестов, проходившая в арабском мире.

События охватывают широкий спектр явлений, начиная с дней рождения и заканчивая войнами. Среди событий можно выделить такие группы как исторические, например, Ледовое побоище, Битва народов, Тридцатилентяя война, и политические - Брексит, протестное движение желтых жилетов во Франции. Классификация событий зависит от того, когда название было определено как историческое и занесено в хроники, исторические справки, источники.

В своей статье об эвентонимах П.Н. Донец опирается на классификацию Роберта-Алана де Богранде, который, в свою очередь, выделяет следующие классы событийных имен в зависимости от их масштаба, культурных и социальных характеристик:

- События транскультурного масштаба (мега-события);

- События национально-культурного масшатаба (макро-события);

- События субкультурного масштаба (медиа-события);

- События личного характера (микро-события). $[13$, c. 36].

Эвентонимы также изучаются лингвистами в рамках такого направления, как теория прецедентности. Прецедентные феномены привлекают внимание лингвистов как носители культурной информации, а также как один из приемов управления восприятием информации и, как следствие, формирования общественного мнения [1, с. 119]. Например, Н.Н. Воропаев относит эвентонимы к именам прецедентным. При этом подходе к эвентонимам относятся прецедентные имена - антропонимы, хрематонимы и идеонимы. Термином эвентоним обозначают разного рода фразеологизмы-идиомы и словесные клише, которые в дискурсе представляют прецедентные ситуации, например, мифические, исторические или вымышленные литературные события [7, с. 39].

Объектом нашего исследования являются эвентонимы, отражающие события национально-культурного и субкультурного масштаба, поскольку именно эти события получают огласку в иностранных СМИ. Мы проанализированы статьи и заголовки статей из разных рубрикаций онлайн-изданий на немецком языке, содержащие 
эвентонимы. В результате были отобраны 72 примера употребления эвентонимов.

В отобранном нами корпусе примеров можно выделить следующие группы эвентонимов:

1. Единицы, отражающие политические события:

Bundeskanzlerin Angela Merkel beschwichtigte erneut, die Arbeitsfähigkeit der GroKo sei nicht gefährdet. (Kpoccмедийный портал «deutschland.de» 05.05.2019 г.). Немецкая аббревиатура GroKo расшифровывается как Große Koalition (коалиция партий ХДС/ХСС и СДПГ в немецком парламенте).

Dieser [Stetter] antwortete: „Wir hatten Merkozy. Vielleicht folgt darauf jetzt Merkollande - und das Verhältnis zwischen Frankreich und Deutschland wird ausgeglichener." (Новостной портал «Евроньюс», 24.04.2012 г.). Союз глав двух государств, Германии и Франции, образованный путем слияния имен глав этих государств, Меркель и Саркози, стал именем самостоятельным.

Doch das Ganze ist eine Falle. Am 17. Mai gelangt das Video an die Öffentlichkeit. «lbiza-Gate» wird nun zu einem politischen Wirbelsturm. (Новостной портал «Евроньюс», 15.02.2020 г.). В Германии активно используется суффикс -гейт для обозначения политических скандалов. В 2013 году данная морфема даже получила статус «англицизм года». Рассмотрим один из таких последних скандалов, произошедших в Австрии в 2019 году. Он был спровоцирован публикацией тайной видеозаписи встречи на Ибице в июле 2017 г., где, как считается, были оппозиционные политики Х.К. Штрахе и Й. Гуденус обсуждали скрытые действия и намерения своей партии. В мае 2019 года шестичасовая запись была предана гласности, разразился скандал, в результате которого в Австрии распалась правящая коалиция и были назначены досрочные выборы.

2. Единицы, отражающие общественные события:

Als Reaktion auf die Silvesternacht haben am Dienstagabend im Bereich des Kölner Hauptbahnhofs mehrere hundert Menschen an einer Demonstration teilgenommen. (Новостной портал «Евроньюс», 07.07.2016г.). В новогоднюю ночь с 31 декабря 2015 года на 1 января 2016 года в Кёльне произошли массовые нападения на женщин, было зарегистрировано более 1000 случаев. Данное событие в немецких СМИ получило краткое и лаконичное название «Silvesternacht», названное, непосредственно, из-за времени, когда случились нападения, в канун Нового года.
Zum ersten Jahrestag der «Gelbwesten»-Proteste in Frankreich ist es in Paris wieder zu massiven Ausschreitungen gekommen. (Кросс медийный портал «deutschland.de» 14.03.2020 г.). Движение «желтых жилетов» - это ежегодная акция протеста, которая началась во Франции и получила свое распространение во всем мире. Демонстрация получила свое название из-за светоотражающих жёлтых жилетов, которые используются участниками с целью показать свою причастность к этому движению.

Wieder wirft eine Dokumentation den Blick auf den Deutschen Herbst - diesmal aus einer durchaus persönlichen Perspektive. (Кросс-медийный портал «deutschland.de» 15.06.2017 г.)

Обычно сочетанием «Deutscher Herbst» обозначают серию террористических атак в Западной Германии осенью 1977 года.

3. Единицы, отражающие культурные явления:

Der französische Präsident Emmanuel Macron hat in einer Rede im Bundestag anlässlich des Volkstrauertages für ein starkes Europa geworben. (Новостной портал «Евроньюс», 18.11.2018г.). Немецкий государственный праздник, день памяти «Volkstrauertag» («День народной скорби») ежегодно отмечается в середине ноября и служит в настоящее время напоминанием о необходимости примирения, понимания и мира.

In Rheinland-Pfalz, Hessen und Baden-Württemberg wird dagegen Fastnacht oder Fas(se)nacht gefeiert, während die sogenannte fünfte Jahrszeit vor allem in Bayern und Sachsen als Fasching bekannt ist. (Кросс медийный портал «deutschland.de» 24.03.2015 г.) В данном примере использован эвентоним, обозначающий народные гуляния. На юго-западе Германии карнавалы перед Великим постом, аналог русской Масленицы, называют «Fastnacht» или «Fasching».

Можно отметить, что эвентонимы являются перспективным объектом лингвистического исследования. Обращение к данным единицам как отдельному объекту исследования позволит выявить, какие события являются наиболее значимыми для отдельной культуры или ряда стран, а возможно, и всего современного мира. Полученные данные можно будет использовать при решении проблем межкультурного взаимодействия, в том числе и перевода, что, несомненно, имеет значение в свете продолжающейся интенсификации межкультурной коммуникации.

\section{ЛИТЕРАТУРА}

1. Быкова Л.В. Творчество Ф. Кафки как сфера-источник прецедентных феноменов в современных российской прессе // Лингвистическое образование на 
современном этапе: российский и зарубежный опыт. Сборник научных статей и материалов Международной конференции. - 2017. - С. 118-125.

2. Велентеенко М.В., Таджибова А. Н. Особенности перевода реалий с русского языка на английский язык на примере романа А.С. Пушкина «Евгений Онегин» // Современная наука: актуальные проблемы теории и практики. Серия: Гуманитарные науки. - 2019. - №03/2. - С. 65-69.

3. Верещагин Е.М. Лингвострановедческая теория слова. - М.: Русский язык, 1980. - 259 с.

4. Верещагин Е.М., Костомаров В.Г. Язык и культура: Лингвострановедение в преподавании русского языка как иностранного. - М.: Русский язык, 1983. - 320 с.

5. Виноградов В.С. Лексические вопросы перевода художественной прозы. - М.: Издательство Московского университета, 1978. - 172 с.

6. Виноградов В.С. Введение в переводоведение (общие и лексические вопросы). - М.: Издательство института общего среднего образования РА0, 2001. $118 \mathrm{c}$.

7. Воропаев Н.Н. 0 проблемах классификации прецедентных имен и других прецедентных феноменов в китайскоязычном дискурсе // Вестник ИГлу. 2012. - №4 (21). $-79 \mathrm{c}$.

8. Комиссаров В.Н. Современное переводоведение. - М.: ЭТС, 1999. - 175 с.

9. Коротких С.А. Ономастика романа «Братья Карамазовы». - Воронеж: Воронежский государственный университет, 2004. - 199 с.

10. Крюкова И.В. Пограничные разряды ономастики в современном русском языке: автореф. канд. филол. наук: 10.02.01. - Волгоград, 1993. - 21 с.

11. Подольская Н.В. Словарь русской ономастической терминологии. М.: Наука, 1988. - 149 с.

12. Суперанская А.В. Общая теория имени собственного / Отв. ред. А.А. Реформатскиц. Изд. 3 е, испр. - М.: Книжный дом «либроком», $2009 .-190$ с.

13. Brendler A., Brendler S. Naturereignisnamen // Namenarten und ihre Erforschung. Ein Lehrbuch für das Studium der Onomastik. - Hamburg: Baar., 2004. - 623 S.

14. Donec P. N. Zum Begriff des Eventonyms // Das Wort: Germanistisches Jahrbuch der GUS 2002. - 220 S.

с Быкова Людмила Владимировна (bykova_Iv@surgu.ru), Таджибова Аксана Наруллаховна (tadzhibova_an@surgu.ru).

Журнал «Современная наука: актуальные проблемы теории и практики»

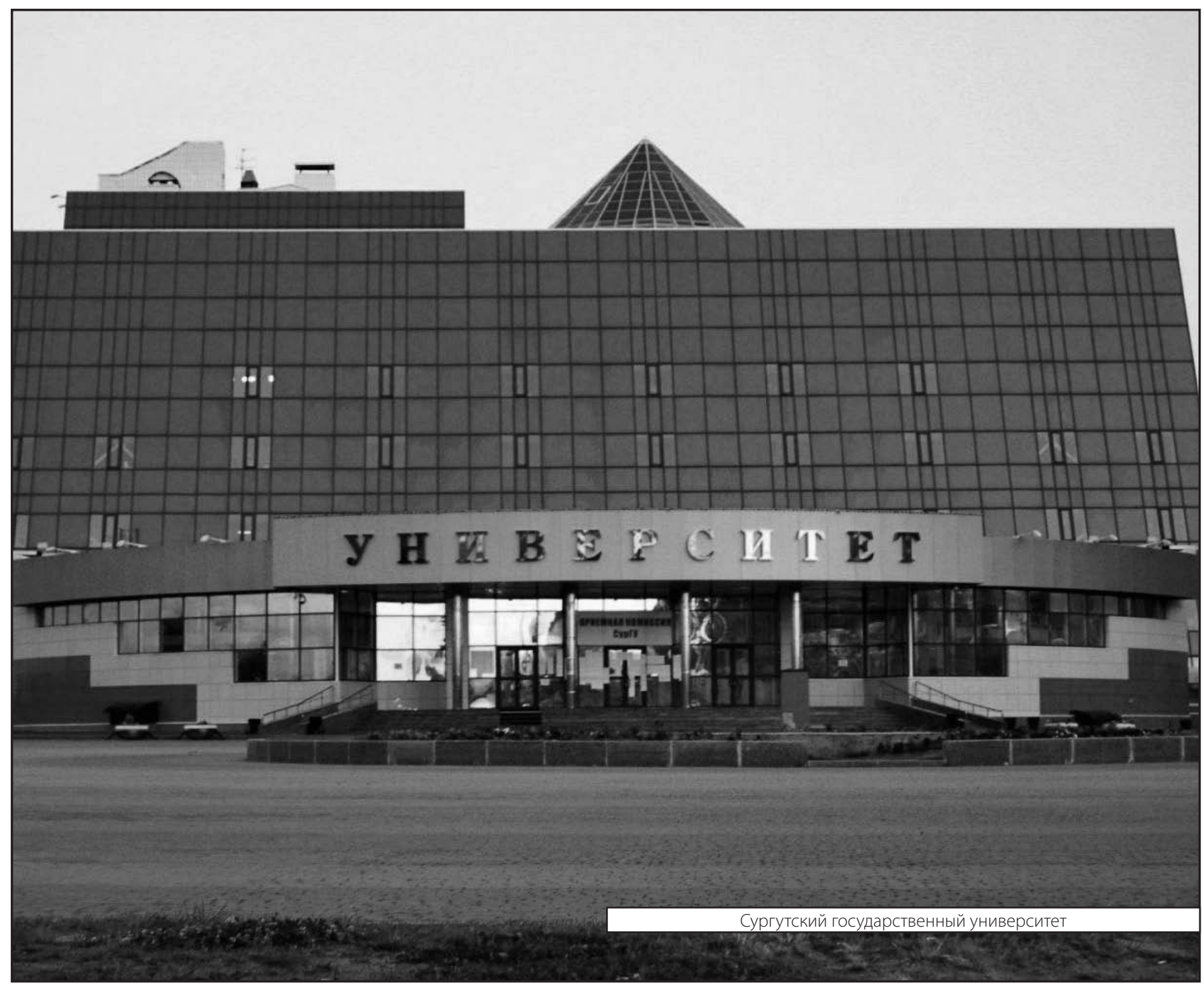

